\title{
Sediment burial dating using terrestrial cosmogenic nuclides
}

\author{
Andreas Dehnert \& Christian SchlÜchter ${ }^{*}$
}

\begin{abstract}
Burial dating using in situ produced terrestrial cosmogenic nuclides is a relatively new method to date sediments and quantify geomorphological processes such as erosion, accumulation and river incision. Burial dating utilises the decay of previously in situ produced cosmogenic nuclides and can be applied to sedimentary deposits such as cave fillings, alluvial fans, river terraces, delta deposits, and dunes. Using the established ${ }^{10} \mathrm{Be} /{ }^{26} \mathrm{Al}$ nuclide pair allows numerical dating of quartz bearing material from $\sim 100 \mathrm{ka}$ to $5 \mathrm{Ma}$, where other dateable material is often unavailable. To date, a number of studies have demonstrated the successful application of in situ produced cosmogenic nuclides in various scientific disciplines, such as Quaternary geology, geomorphology and palaeoanthropology. However, insufficiently defined physical properties such as nuclide half lives and complex depth dependent nuclide production rates result in relatively large uncertainties. Nevertheless, burial dating represents a promising method for determining numerical ages.
\end{abstract}

\section{[Datierung des Überdeckungsalters mit Hilfe von terrestrischen kosmogenen Nukliden]}

Kurzfassung: Die Methode der Bestimmung des Überdeckungsalters mit Hilfe von in situ produzierten terrestrischen kosmogenen Nukliden stellt ein verhältnismäßig neues Datierverfahren dar. Es ermöglicht die Altersbestimmung von Sedimenten und damit die Quantifizierung von geomorphologischen Prozessen, wie Erosion, Akkumulation und Flusseintiefung. Das Verfahren bedient sich dabei des Zerfalls von zuvor in situ produzierten kosmogenen Nukliden und kann auf sedimentäre Ablagerungen wie Höhlenfüllungen, Schwemmfächer, Flussterrassen, Deltaschüttungen und Dünen angewendet werden. Durch die Verwendung des erprobten ${ }^{10} \mathrm{Be} /{ }^{26} \mathrm{Al}$ Nuklidpaares erlaubt die Methode die Bestimmung eines numerischen Alters von quarzführendem Material über einen Zeitbereich von $\sim 100 \mathrm{ka} \mathrm{bis} 5 \mathrm{Ma}$. In diesem Zeitabschnitt ist datierfähiges Material für andere Methoden oftmals nicht oder nur unzureichend vorhanden. Viele Studien konnten bereits die erfolgreiche Anwendung von in situ produzierten kosmogenen Nukliden in den verschiedensten wissenschaftlichen Bereichen, darunter zum Beispiel in der (Quartär)Geologie, Geomorphologie und Paläoanthropologie, belegen. Dennoch können die zur Zeit nur ungenügend genau bestimmten physikalischen Größen, wie zum Beispiel die Nuklidhalbwertszeiten oder die tiefenabhängigen Nuklidproduktionsraten zu vergleichsweise großen Unsicherheiten führen. Trotz dieser Nachteile stellt die Methode eine vielversprechende Möglichkeit der numerischen Altersbestimmung dar.

Keywords: cosmogenic nuclides, burial dating, numerical age determination, sediment, geochronology

\footnotetext{
*Addresses of authors: A. Dehnert, C. Schlüchter, Institut für Geologie, Universität Bern, Baltzerstrasse 1+3, 3012 Bern, Switzerland. E-Mail: andreas.dehnert@geo.unibe.ch
} 


\section{Introduction}

Sedimentary archives, for example marine, terrestrial and glacial deposits, provide information regarding the climatic and environmental history as well as the tectonic development of a given area. In this context, the youngest part of the Earth' history, the Neogene and the Quaternary, are of particular interest. This time have been characterised by massive mountain forming processes, large changes in the temperature of oceans and the atmosphere as well as by important biological evolution, particularly with the appearance of early and modern hominids (Asfaw et al. 1999; CLARK et al. 2003; DÈZES et al. 2004; RAVELo et al. 2004; GIBBARD et al. 2005). All this information, however, is only of minor value if it can not be integrated into a global chronological framework. Only with reliable dating can such comparisons be made and the dating of sediments of the past million years is, therefore, one of the most important tasks in modern Quaternary research.

Dating of terrestrial sediments over long time periods, however, can often be highly complex, imprecise or even impossible. Available methods, for example radiocarbon and luminescence dating, cover up to $50 \mathrm{ka}$ and a few $100 \mathrm{ka}$, respectively, only a relatively short part of the Quaternary (PREUSSER et al. 2008, HAJDAS 2008). We are presenting here a brief summary on recent developments in using terrestrial cosmogenic nuclides for dating the burial age of sediments. Burial dating is based on the assumption that rocks that have been exposed to cosmic radiation for a given time are enriched with various cosmogenic radionuclides (Fig. 1). When these rocks, or their erosional products, are shielded from cosmic radiation, nuclide production ceases and the radionuclides decay according to their individual half lives (Fig. 2). Shielding may be due to transportation of sediment into a cave, by covering with overburden or by deposition in a deep water body (Fig. 3). By measuring the concentration of two nuclides (at least one radionuclide), it is possible to date the time elapsed since shielding.
Cosmogenic nuclides are produced by nuclear reactions in the Earth's atmosphere as well as in the upper parts of the Earth's crust. These nuclear reactions are initiated by high energy secondary cosmic radiation (LAL \& Peters 1967). The development of accelerator mass spectrometry (AMS) over the past few decades has enabled the detection of very small amounts of cosmogenic nuclides (Finkel \& Suter 1993) and is fundamental to the effective use of cosmogenic nuclides in modern geosciences.

The radionuclides ${ }^{10} \mathrm{Be}$ and ${ }^{26} \mathrm{Al}$ are good candidates for burial dating: both are produced in situ in quartz and possess relatively long half lives. Quartz is one of the most common minerals in the Earth's crust and so is present in almost all sedimentary deposits. The long half lives of both radionuclides enable dating over a time period of $5 \mathrm{Ma}$ and, in addition to this, the nuclide production ratio has been quantified and is independent of latitude, altitude, depth below surface and time (Gosse \& PHILlips 2001). For these reasons, the method of burial dating is independent of production rate changes in time and space (LAL \& ARNOLD 1985; Klein et al. 1986; LAL 1991), which causes most of the inaccuracies in surface exposure dating (Gosse \& Phillips 2001; Ivy-Ochs \& Kober 2008).

The principle of burial dating was proposed by LAL \& ARNOLD (1985) and underwent a major revision by LAL (1991). The first application of burial dating published (KLEIN et al. 1986) was able to show, with the analysis of the ${ }^{26} \mathrm{Al} /{ }^{10} \mathrm{Be}$ ratio, that the Libyan Desert Glass Field was occasionally covered by shifting sand dunes, although it was not possible at this time to give discrete burial ages for the sampled glass. GRANGER et al. (1997) were the first to date a deposition event by using the ${ }^{26} \mathrm{Al} /{ }^{10} \mathrm{Be}$-ratio. They determined river down-cutting rates for the past 1.5 Ma using relocated sediments from cave fillings. Since these first applications a few studies have demonstrated the successful application of burial dating. In addition to the more application focused studies, reviews by GRANGER \& MUZIKAR (2001) and more recently by GRANGER (2006) provide the basic knowledge needed for age calculations in various burial scenarios. 
As already mentioned, the method of burial dating with cosmogenic nuclides is based on the decay of radionuclides. This requires dependable accuracy in half life determination and precision of the nuclide measurement itself. The half life of ${ }^{26} \mathrm{Al}$ of $0.702 \pm 0.056 \mathrm{Ma}$ (MidDLETON et al. 1983), $0.705 \pm 0.024 \mathrm{Ma}$ (NorRIs et al. 1983), or $0.716 \pm 0.032 \mathrm{Ma}$ (Rightmire et al. 1958) is well defined and widely accepted in the cosmogenic nuclide community. However, the traditionally recognised half life of ${ }^{10} \mathrm{Be}$ of $1.51 \pm 0.06 \mathrm{Ma}$ (Hofmann et al. 1987) is still undergoing discussion. Some authors (e.g. Partridge et al. 2003; Häuselmann \& Granger 2005; Granger et al. 2006) believe that this figure is too high and suggest a shorter ${ }^{10} \mathrm{Be}$ half life of $\sim 1.34 \mathrm{Ma}$ (MiddLEton et al. 1993). Nishizzumi et al. (2007) support this, having recently re-evaluated the commonly used ICN (ICN Chemical \& Radioisotope Division) and NIST (National Institute of Standards and Technology) reference material, suggesting that the ${ }^{10} \mathrm{Be}$ half life should be lowered to 1.36 $\pm 0.07 \mathrm{Ma}$. On the other hand, FinK \& SMITH (2007) also re-evaluated the same material but hesitated to lower the ${ }^{10} \mathrm{Be}$ half life, stating that the direct and accurate specific activity measurement of the parent solution of both standards is needed to calculate the ${ }^{10} \mathrm{Be}$ half life, but this is not yet available.

\section{In situ production of cosmogenic ${ }^{10} \mathrm{Be}$ and ${ }^{26} \mathrm{Al}$}

The Earth's atmosphere is undergoing permanent bombardment by primary cosmic radiation. This high energy nucleon radiation originates mainly in the Milky Way (with $\mathrm{E} \approx 1-10^{10} \mathrm{GeV}$ ), with a much smaller fraction descended from beyond our galaxy $\left(\mathrm{E}<10^{20} \mathrm{eV}\right)(\mathrm{Gosse} \&$ Phillips

Table 1: Constants for production rate and burial age calculations with in situ produced ${ }^{10} \mathrm{Be}$ and ${ }^{26} \mathrm{Al}$ extracted from quartz minerals. SLHL $=$ sea level, high latitude $\left(>60^{\circ}\right)$

Tab. 1: Zusammenstellung der Konstanten für die Produktionsraten- und Altersbestimmung mit in situ produziertem ${ }^{10} \mathrm{Be}$ und ${ }^{26} \mathrm{Al}$ aus Quarz. SLHL (sea level, high latitude) $=$ Meeresspiegel, hohe Breiten $\left(>60^{\circ}\right)$

\begin{tabular}{|c|c|c|c|}
\hline Constant & ${ }^{10} \mathrm{Be}$ & ${ }^{26} \mathrm{Al}$ & reference \\
\hline half life $\mathrm{t}_{1 / 2}(\mathrm{Ma})$ & $\begin{array}{l}1.36 \pm 0.07^{*} \\
1.51 \pm 0.06^{\wedge}\end{array}$ & $0.705 \pm 0.024^{\#}$ & $\begin{array}{l}{ }^{*} \text { Nishiizumi et al. (2007) } \\
{ }^{\wedge} \text { Hofmann et al. (1987) } \\
\quad \text { NorRis et al. (1983) }\end{array}$ \\
\hline $\begin{array}{l}\text { total surface production rate }{ }_{\text {SLHL }} \mathrm{P} \\
\text { at SLHL }\left(\text { atoms } \mathrm{g}^{-1} \mathrm{a}^{-1}\right)\end{array}$ & $5.1 \pm 0.3$ & $31.1 \pm 1.9$ & Stone (2000) \\
\hline $\begin{array}{l}\text { negative muonic surface production rate } \\
\left.{ }_{\text {SLHL }} P_{1 \mu-} \text { at SLHL (atoms g } \mathrm{g}^{-1} \mathrm{a}^{-1}\right)\end{array}$ & 0.096 & 0.723 & Granger \& Smith (2000) \\
\hline $\begin{array}{l}\text { negative muonic surface production rate } \\
\mathrm{SL}_{2 \mu-} \text { at SLHL (atoms g } \mathrm{a}^{-1} \text { ) }\end{array}$ & 0.021 & 0.156 & GRANGER \& SMith (2000) \\
\hline $\begin{array}{l}\text { fast muonic surface production rate }{ }_{\text {SLHL }} \mathrm{P}_{\mu+} \\
\text { at SLHL (atoms } \mathrm{g}^{-1} \mathrm{a}^{-1} \text { ) }\end{array}$ & 0.026 & 0.192 & Granger \& SMith (2000) \\
\hline $\begin{array}{l}\text { nucleonic surface production rate }{ }_{\mathrm{SLHL}} \mathrm{P}_{\mathrm{N}} \\
\left.\text { at SLHL (atoms } \mathrm{g}^{-1} \mathrm{a}^{-1}\right)\end{array}$ & 4.957 & 30.029 & with $\mathrm{P}=\mathrm{P}_{\mathrm{N}}+\mathrm{P}_{1 \mu-}+\mathrm{P}_{2 \mu-}+\mathrm{P}_{\mu+}$ \\
\hline nucleon attenuation length $\Lambda_{\mathrm{N}}\left(\mathrm{g} \mathrm{cm}^{-2}\right)$ & \multicolumn{2}{|c|}{$160 \pm 10$} & Granger \& SMith (2000) \\
\hline negative muon attenuation length $\Lambda_{1 \mu-}\left(\mathrm{g} \mathrm{cm}^{-2}\right)$ & \multicolumn{2}{|c|}{738.6} & Granger \& SMith (2000) \\
\hline negative muon attenuation length $\Lambda_{2 \mu-}\left(\mathrm{g} \mathrm{cm}^{-2}\right)$ & \multicolumn{2}{|c|}{2688} & GRANGER \& SMIth (2000) \\
\hline fast muon attenuation length $\Lambda_{\mu^{+}}\left(\mathrm{g} \mathrm{cm}^{-2}\right)$ & \multicolumn{2}{|c|}{4360} & Granger \& SMith (2000) \\
\hline
\end{tabular}


2001). Interactions of incoming primary radiation with atoms of the Earth's atmosphere result in low-energy particles, traditionally known as "secondary cosmic radiation" $(\mathrm{E} \approx 100 \mathrm{MeV})$. For the in situ production of ${ }^{10} \mathrm{Be}$ and ${ }^{26} \mathrm{Al}$, both at the rock surface and subsurface level, there are two kinds of relevant particles: nucleons (neutrons and protons) and muons (fast and negative). According to strict nomenclature rules, muons belong to tertiary cosmic radiation, as they are a byproduct of decaying secondary cosmic radiation pions ( $\pi$ mesons) (Gosse \& Phillips 2001). Cosmogenic ${ }^{10} \mathrm{Be}$ and ${ }^{26} \mathrm{Al}$ are generated in quartz $\left({ }^{16} \mathrm{O}\right.$ as the main target for ${ }^{10} \mathrm{Be}$ and ${ }^{28} \mathrm{Si}$ transforms to ${ }^{26} \mathrm{Al}$ ) by spallation reactions (neutrons), negative muon capture, and a cascade of reactions called Coulomb-reactions (fast muons). These processes are explained in detail in Lal \& Peters (1967) and Gosse \& PhilLIPS (2001), among others. Nuclide production in near surface material is dominated by nucleons ( 97.5\%)(HeISINGER 1998) and changes with increasing depth, as muons display greater penetration depth as a result of their lower reactivity. The nucleonic production as a function of depth can be shown as a simple exponential law (LAL 1991; Brown et al. 1992; Gosse \& Phillips 2001):

$$
\begin{aligned}
& P_{10 N}(z)=P_{10 N}(0) e^{-\rho z / \Lambda_{N}} \\
& P_{26 N}(z)=P_{26 N}(0) e^{-\rho z / \Lambda_{N}}
\end{aligned}
$$

with production rate in depth in atoms $\mathrm{g}^{-1} \mathrm{a}^{-1}$ $(\mathrm{P}(\mathrm{z}))$, scaled surface production rate in atoms $\mathrm{g}^{-1} \mathrm{a}^{-1}(\mathrm{P}(0))$, depth in $\mathrm{cm}(\mathrm{z})$, attenuation length in $\mathrm{g} \mathrm{cm}^{-2}(\Lambda)$ and density of the overburden in $\mathrm{g} \mathrm{cm}^{-3}(\rho)$. The index of 10 and 26 represents the nuclides ${ }^{10} \mathrm{Be}$ and ${ }^{26} \mathrm{Al}$, respectively, and $\mathrm{N}$ nucleonic production. Constants for all equations are listed in Tab. 1.

The nuclide production by muons is valid within a depth range of $200-5000 \mathrm{~g} \mathrm{~cm}^{-2}$ and is well described by the sum of three exponential functions (Granger \& SMith 2000). At shallower depths nuclide production by muons is negligible, as nucleonic production is predominant. Nuclide production by negative muon capture is described in the first two terms. The last one represents production by Coulomb-reactions (Granger \& SMith 2000; Granger \& MUZIKAR 2001):

$$
\begin{aligned}
& \mathrm{P}_{10 \mu}(\mathrm{z})=\mathrm{P}_{10 / 1 \mu-}(0) \mathrm{e}^{-\rho \mathrm{z} / \Lambda_{1 \mu-}}+ \\
& \mathrm{P}_{10 / 2 \mu-}(0) \mathrm{e}^{-\rho \mathrm{z} / \Lambda_{2 \mu-}}+\mathrm{P}_{10 \mu+}(0) \mathrm{e}^{-\rho \mathrm{z} / \Lambda_{\mu+}} \\
& \mathrm{P}_{26 \mu}(0)=\mathrm{P}_{26 / 1 \mu-}(0) \mathrm{e}^{-\rho \mathrm{z} / \Lambda_{1 \mu-}}+ \\
& \mathrm{P}_{26 / 2 \mu-}(0) \mathrm{e}^{-\rho \mathrm{z} / \Lambda_{2 \mu-}}+\mathrm{P}_{26 \mu+}(0) \mathrm{e}^{-\rho \mathrm{z} / \Lambda_{\mu+}}
\end{aligned}
$$

The index $\mu$ represents muonic production, + and - show fast and negative muons respectively.

The scaled surface production rate, sometimes called local production rate, is dependent on altitude above sea level and latitude, due to the effects of the Earth's magnetic field on the se-



Fig. 1: Increasing nuclide concentration of ${ }^{10} \mathrm{Be}$ and ${ }^{26} \mathrm{Al}$ in quartz over time. Plotted for the ideal case for exposure at SLHL with unshielded flat surface and no erosion. Used parameters are listed in Tab. 1.

Abb. 1: Darstellung der Konzentrationsentwicklung der Nuklide ${ }^{10} \mathrm{Be}$ und ${ }^{26} \mathrm{Al}$ für den Fall der Bestrahlung unter SLHL Bedingungen einer nicht erodierenden, nicht abgeschirmten, ebenen, Quarzoberfläche. Zu Grunde liegende Parameter können Tab. 1 entnommen werden. 


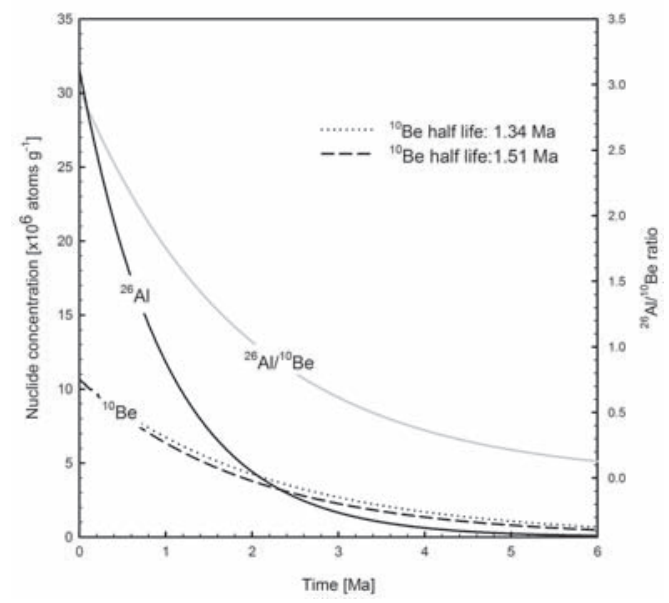

Fig. 2: Decreasing ${ }^{26} \mathrm{Al} /{ }^{10} \mathrm{Be}$ ratio (in gray) and individual nuclide concentration of ${ }^{10} \mathrm{Be}$ (dashed and dotted) and ${ }^{26} \mathrm{Al}$ (solid) in quartz over time with complete shielding from cosmic radiation after reaching individual saturation. Used parameters are listed in Tab. 1.

Abb. 2: Darstellung der Abnahme des ${ }^{26} \mathrm{Al} /{ }^{10} \mathrm{Be}$ Verhältnisses (in grau) sowie der Nuklidkonzentration von ${ }^{10} \mathrm{Be}$ (gestrichelt und gepunktet) und ${ }^{26} \mathrm{Al}$ (durchgezogen) in Quarz bei vollständiger Abschirmung der kosmischen Strahlung. Ausgangskonzentrationen entsprechen vollständiger Sättigung. $\mathrm{Zu}$ Grunde liegende Parameter können Tab. 1 entnommen werden.

condary cosmic rays and the attenuation effect of the atmosphere itself. Its value and scaling for the sampling position is also under debate at the moment, and is discussed in more detail in Lal (1991), Dunai (2000), Stone (2000), WaGNER et al. (2000), Desilets \& ZReda (2001), and references therein.

The nuclides ${ }^{10} \mathrm{Be}$ and ${ }^{26} \mathrm{Al}$ are also produced in situ by non-cosmogenic such as radiogenic reactions. Sharma \& Middleton (1989) stated that only $\alpha$-induced nuclear reactions could provide a significant portion of ${ }^{10} \mathrm{Be}$ and ${ }^{26} \mathrm{Al}$. Lithium as target nuclei for production of ${ }^{10} \mathrm{Be}$ $\left({ }^{7} \mathrm{Li}(\alpha, \mathrm{p})^{10} \mathrm{Be}\right)$ is normally present at trace levels $\left(\mu \mathrm{g} \mathrm{g}^{-1}\right)$ but sodium, as a source of ${ }^{26} \mathrm{Al}$ $\left({ }^{23} \mathrm{Na}(\alpha, \mathrm{p})^{26} \mathrm{Al}\right)$, is nearly always present at concentrations of one or more percent. Hence, ${ }^{10} \mathrm{Be}$ production is quite small compared to the cosmogenic compound and therefore negligible, while that of ${ }^{26} \mathrm{Al}$ may be significant. Brown et al. (1991), however, argued that the steady-state concentrations of radiogenically produced ${ }^{26} \mathrm{Al}$ in average sandstones is

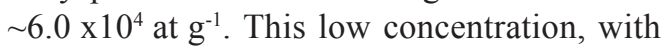
respect to steady-state concentrations of cosmogenically produced ${ }^{26} \mathrm{Al}$ of $\sim 3.2 \times 10^{7}$ at $^{-1}$ (Fig. $1 \& 2$ ), will only be significant in samples with a "short" exposure history. Beside this, no relevant radiogenic ${ }^{26} \mathrm{Al}$ contamination in quartz has ever been observed and reported so far.

\section{Application of burial dating}

The following chapter looks at different kinds of burial situation and is designed to give an overview of the required formulas, followed by selected examples. For more detailed information see Granger \& SMith (2000) and Granger \& MUZIKAR (2001).

\subsection{Single stage exposure history - cave sediments}

The simplest case of burial is provided by cave sediments (Fig. 4), in that shielding from cosmic rays occurs quickly and effectively to inwashed sediments. The great advantage of these deposits is that they remain almost unaffected by cosmic radiation and thus only negligible post burial production results. Assuming steady-state erosion conditions for the sediments, the burial age is directly dependent on nuclide half-lives. Thus today's ${ }^{26} \mathrm{Al} /{ }^{10} \mathrm{Be}$ ratio gives us the burial age ( $\mathrm{t}$ in years) solving equation 5 and 6 for ${ }^{10} \mathrm{Be}$ and ${ }^{26} \mathrm{Al}$.

$$
\begin{aligned}
& \mathrm{N}_{10}(\mathrm{t})=\frac{\mathrm{P}_{10}}{1 / \tau_{10}+\rho \varepsilon / \Lambda} \mathrm{e}^{-\mathrm{t} / \tau_{10}} \\
& \mathrm{~N}_{26}(\mathrm{t})=\frac{\mathrm{P}_{26}}{1 / \tau_{26}+\rho \varepsilon / \Lambda} \mathrm{e}^{-\mathrm{t} / \tau_{26}}
\end{aligned}
$$

Equation 5 and 6 can be combined to equation 7 


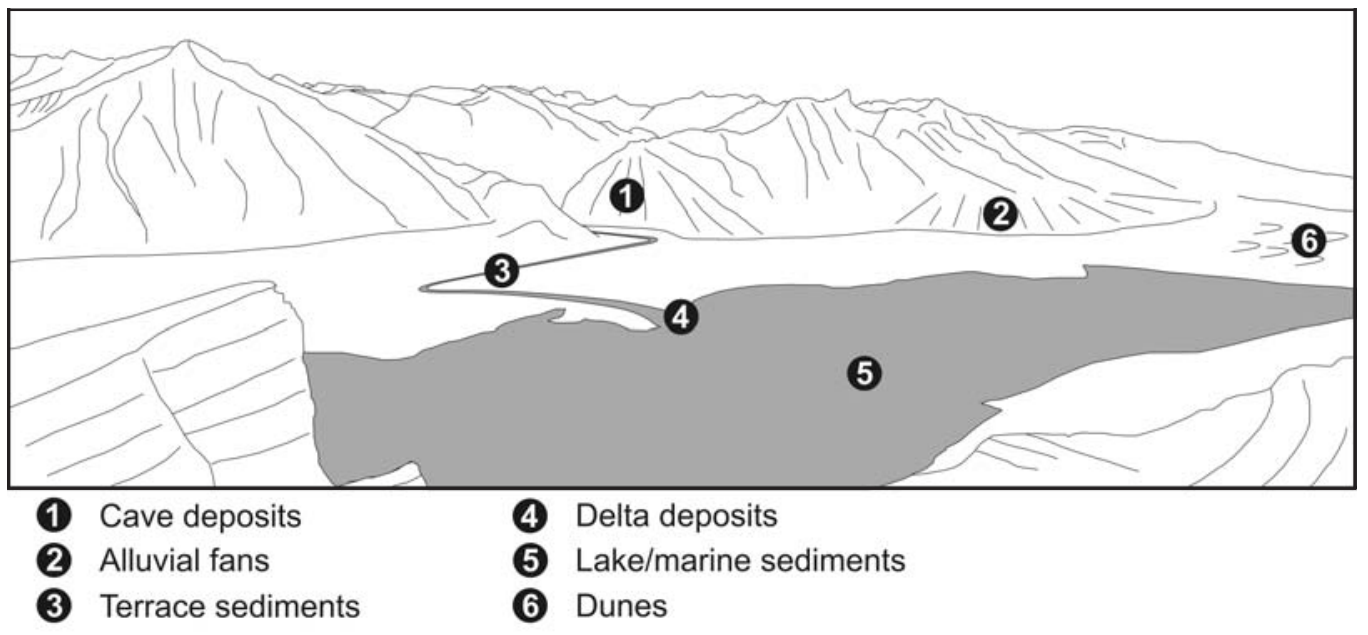

Fig. 3: Overview sketch of potential dateable sedimentary deposits with the cosmogenic burial dating technique. Quick shielding from cosmic radiation is achieved by washing into deep underground (1), covering with sediment $(2,3,4,6)$ or water $(4,5)$.

Abb. 3: Übersichtsdarstellung der potenziellen geologischen Archive, welche mit Hilfe des burial dating Verfahrens datiert werden können. Die notwendige rasche Abschirmung der kosmischen Strahlung kann erreicht werden durch Umlagerung in den tieferen Untergrund (1), Überdeckung durch Sediment $(2,3,4,6)$ oder Wasser $(4,5)$.

$$
\begin{aligned}
& \frac{\mathrm{N}_{26}(\mathrm{t})}{\mathrm{N}_{10}(\mathrm{t})}=\frac{\mathrm{P}_{26}}{\mathrm{P}_{10} \tau_{10} / \tau_{26}}\left(1 / \tau_{10}+\rho \varepsilon / \Lambda\right)^{\tau_{10} / \tau_{26}} \\
& \left(1 / \tau_{26}+\rho \varepsilon / \Lambda\right)^{-1}\left(\mathrm{~N}_{10}(\mathrm{t})\right)^{\tau_{26} / \tau_{10}-\tau_{10} \tau_{26}}
\end{aligned}
$$

GRANGER et al. (1997) were the first to use the ${ }^{26} \mathrm{Al}-{ }^{10} \mathrm{Be}$ pair to date burial events of sediments. They dated quartz pebbles found in various caves within dolomites along the New River, between Eggleston and Pearisburg, Virginia, USA. The pebbles, quartz vein remnants of metamorphic host rocks in New River's headwaters, were sampled in numerous cave levels up to $35 \mathrm{~m}$ above the modern river. By dating the inwash events of these pebbles from $0.29 \pm 0.18 \mathrm{Ma}$ to $1.47 \pm 0.22 \mathrm{Ma}$, Granger et al. (1997) were able to calculate river incisions rates for the New River of $30.2 \pm 5.5 \mathrm{~m} \mathrm{Ma}^{-1}$ at Pearisburg and $19.7 \pm 3.2 \mathrm{~m} \mathrm{Ma}^{-1}$ at Eggleston, with a mean rate of $27.3 \pm 4.5 \mathrm{~m} \mathrm{Ma}^{-1}$.

Granger et al. (2001) conducted similar studies at the Mammoth Cave multi level system in Kentucky, USA. By analysing the ${ }^{26} \mathrm{Al} /{ }^{10} \mathrm{Be}$ ratio of 29 quartz gravel and sand deposits throughout the cave system and from its surface, they were able to reconstruct a water table history for the nearby Green and Ohio Rivers over the past 3.5 Ma. Furthermore, they demonstrated a glacial influence on the Ohio River behaviour with increasing incision $(\sim 1.5 \mathrm{Ma}$ and $\sim 1.2 \mathrm{Ma})$ followed by aggradation $(0.7$ $-0.8 \mathrm{Ma})$.

More recently, Haeuselmann et al. (2007) looked at glacially accelerated valley incision. Cave infill sediments were used to identify accelerated incision rates (up to $1.2 \mathrm{~km} \mathrm{Ma}^{-1}$ ) in the River Aare valley, between 0.8 to $1.0 \mathrm{Ma}$, in the Siebenhengste-Hohgant cave system, Switzerland.

Archaeological, as well as geological, questions can be solved using burial dating with ${ }^{10} \mathrm{Be}$ and ${ }^{26} \mathrm{Al}$ (see also AKÇAR et al. 2008). Dating of embedded bones is mostly done using U/Th dating of surrounding calcite layers (PICKERING et al. 2007). In the absence of speleothems or with unsuitable U/Th con- 




Fig. 4: Cave scenario: Exposed quartz-containing sediment or soil gets complete shielded by washing into a deep cave. Embedded fossils or artefacts can be dated by detecting the ${ }^{26} \mathrm{Al} /{ }^{10} \mathrm{Be}$ ratio of the surrounding sediment.

Abb. 4: Höhlenszenario: Bestrahltes(r) quarzführendes(r) Sediment oder Boden wird in eine Höhle umgelagert und hierdurch vollständig von der kosmischen Strahlung abgeschirmt. Die Altersbestimmung von eingebetteten Fossilien oder Artefakten kann dann durch die Bestimmung des ${ }^{26} \mathrm{Al} /{ }^{10} \mathrm{Be}$ Verhältnisses des umgebenen, zuvor eingespülten Materials erfolgen.

ditions, dating can also be done with the help of inwash sediments containing quartz. Lower Pliocene hominid remains form Sterkfontein cave, South Africa were dated indirectly by burial dating of the surrounding sediment by PARTRIDGe et al. (2003). The fossils are encased in a breccia of dolomite, chert and surface soil that accumulated as debris dropped into the cave. PARTRIDGe et al. (2003) utilised this fact to obtain burial ages from the quartz bearing material. Palaeomagnetic signals in calcitic flowstones dated the sediment layer containing hominid fossils into a timeframe ranging from 3.22 to $3.58 \mathrm{Ma}$. PARTRIDGE et al. (2003) dated this layer using the ${ }^{26} \mathrm{Al} /{ }^{10} \mathrm{Be}$ ratio to $4.17 \pm 0.14 \mathrm{Ma}$ in the Silberberg Grotto and the previously undated fossil layer in Jacovec Cavern to $4.02 \pm 0.27 \mathrm{Ma}$. Although, these burial ages are in good agreement they are currently under debate (see WALKER et al. 2006).

\subsection{Multiple stage exposure history - Nuclide profiling}

Post burial nuclide production can not be ignored where sediment has only few metres of overburden, as can be done in the cave scenario described above. The post burial production is depth- and time-dependent (see chapter 2) and thus the relevant equations for both nuclides become:

$$
\begin{gathered}
\mathrm{N}_{10}(\mathrm{z}, \mathrm{t})=\mathrm{N}_{10 / \mathrm{inh}} \mathrm{e}^{-\mathrm{t} / \tau_{10}}+ \\
\int_{0}^{\mathrm{t}}\left[\mathrm{P}_{10 \mathrm{~N}}\left(\mathrm{z}+\rho \varepsilon \mathrm{t}^{\prime}\right)+\mathrm{P}_{10 \mu}\left(\mathrm{z}+\rho \varepsilon \mathrm{t}^{\prime}\right)\right] \mathrm{e}^{-\mathrm{t}^{\prime} / \tau_{10}} \partial \mathrm{t}^{\prime}
\end{gathered}
$$

$$
\mathrm{N}_{26}(\mathrm{z}, \mathrm{t})=\mathrm{N}_{26 / \text { inh }} \mathrm{e}^{-\mathrm{t} / \tau_{26}}+
$$

$\int_{0}^{\mathrm{t}}\left[\mathrm{P}_{26 \mathrm{~N}}\left(\mathrm{z}+\rho \varepsilon \mathrm{t}^{\prime}\right)+\mathrm{P}_{26 \mu}\left(\mathrm{z}+\rho \varepsilon \mathrm{t}^{\prime}\right)\right] \mathrm{e}^{-\mathrm{t}^{\prime} / \tau_{26}} \partial \mathrm{t}^{\prime}$

Following Granger \& SMith (2000) the above integrals can be expressed as equation 10 :

$$
\begin{aligned}
& \mathrm{N}_{\mathrm{i}}(\mathrm{z}, \mathrm{t})=\mathrm{N}_{\mathrm{i} / \text { inh }} \mathrm{e}^{-\mathrm{t} / \tau_{\mathrm{i}}} \\
& +\left[\mathrm{P}_{\mathrm{iN}} \mathrm{e}^{-\rho \mathrm{\rho} / \Lambda_{\mathrm{N}}} /\left(1 / \tau_{\mathrm{i}}+\rho \varepsilon / \Lambda_{\mathrm{N}}\right)\right]\left[1-\mathrm{e}^{-\mathrm{t}\left(1 / \tau_{\mathrm{i}}+\rho \varepsilon / \Lambda_{\mathrm{N}}\right)}\right] \\
& +\left[\mathrm{P}_{\mathrm{i} / 1 \mu-} \mathrm{e}^{-\rho z / \Lambda_{1 \mu-}} /\left(1 / \tau_{\mathrm{i}}+\rho \varepsilon / \Lambda_{1 \mu-}\right)\right]\left[1-\mathrm{e}^{-\mathrm{t}\left(1 / \tau_{\mathrm{i}}+\rho \varepsilon / \Lambda_{1 \mu-}\right)}\right] \\
& +\left[\mathrm{P}_{\mathrm{i} / 2 \mu-} \mathrm{e}^{-\rho z / \Lambda_{2 \mu-}} /\left(1 / \tau_{\mathrm{i}}+\rho \varepsilon / \Lambda_{2 \mu-}\right)\right]\left[1-\mathrm{e}^{-\mathrm{t}\left(1 / \tau_{\mathrm{i}}+\rho \varepsilon / \Lambda_{2 \mu-}\right)}\right] \\
& +\left[\mathrm{P}_{\mathrm{i} \mu+} \mathrm{e}^{-\rho z / \Lambda_{\mu+}} /\left(1 / \tau_{\mathrm{i}}+\rho \varepsilon / \Lambda_{\mu+}\right)\right]\left[1-\mathrm{e}^{-\mathrm{t}\left(1 / \tau_{\mathrm{i}}+\rho \varepsilon / \Lambda_{\mu+}\right)}\right]
\end{aligned}
$$

The index $\mathrm{i}$ represents either the nuclide ${ }^{10} \mathrm{Be}$ or ${ }^{26} \mathrm{Al}$. Each of equation 8 and 9 contains three unknowns (burial age, inherited nuclide concentration and erosion rate). Thus, a combination of [8] and [9] can not be solved uniquely by only analysing ${ }^{10} \mathrm{Be}$ and ${ }^{26} \mathrm{Al}$ in one sample at a specific depth. The solution for this problem lies in sampling a vertical profile within the deposit. By analysing two samples from the same profile and considering suitable constraints for the inherited nuclide concentration [8] and [9] can be solved uniquely. These assumptions are site-specific and may comprise of, for example, a constant inherited nuclide concentration 
across the profile or a known inherited ${ }^{26} \mathrm{Al} /$ ${ }^{10} \mathrm{Be}$ ratio. The model solutions from [8] and [9] need to be fitted to the field observations (measured nuclide concentrations). This can be done by least squares regression or other suitable optimisation techniques. Collecting more than two samples overconstrains the model solution, resulting in reduced random errors and yields a more robust detection of systematic deviations.

The first use of nuclide profiling to obtain sediment burial ages was done by GRANGER $\&$ Sмiтн (2000). They measured the ${ }^{10} \mathrm{Be}$ and ${ }^{26} \mathrm{Al}$ concentrations of nine samples in a $\sim 10 \mathrm{~m}$ profile of a river terrace of Old Kentucky River at Rice Station, Kentucky, USA. The sandy sediment was rapidly deposited, perhaps at the shores of a rising proglacial lake, and has remained exposed since deposition. By solving an equation similar to [8] and [9] and leastsquare-fitting of the solutions, they dated the terrace formation to $1.50^{+0.32} /_{-0.25} \mathrm{Ma}$ with a post-depositional terrace erosion rate of 6.2 $\pm 0.2 \mathrm{~m} \mathrm{Ma}^{-1}$. This is in good agreement with the nearby Green River incision around 1.5 Ma (GrANGER et al. 2001, see above).

This initial study was followed by dating of alluvial deposits above the San Juan River near Bluff and Mexican Hat, Utah, USA by WolkoWINSKY \& GRANGER (2004). Their cosmogenic ${ }^{10} \mathrm{Be}$ and ${ }^{26} \mathrm{Al}$ data suggest a deposition age of $1.36^{+0.20}{ }_{-0.15}$ Ma and an erosion rate of 14 $\pm 4 \mathrm{~m} \mathrm{Ma}^{-1}$ for the $\sim 12 \mathrm{~m}$ thick Bluff site. Additional to $\mathrm{t}$ and $\varepsilon$, they allowed a fit within the model for bulk density and the addition of, at most, $20 \mathrm{~cm}$ material on top of the sampled profile. They were not able to realise dates for the Mexican Hat site due to insufficient burial depth of only $5.5 \mathrm{~m}$ following Granger \& MuZIKAR (2001).

The more recent work of HäUSELMANN et al. (2007) utilises the nuclide profiling technique
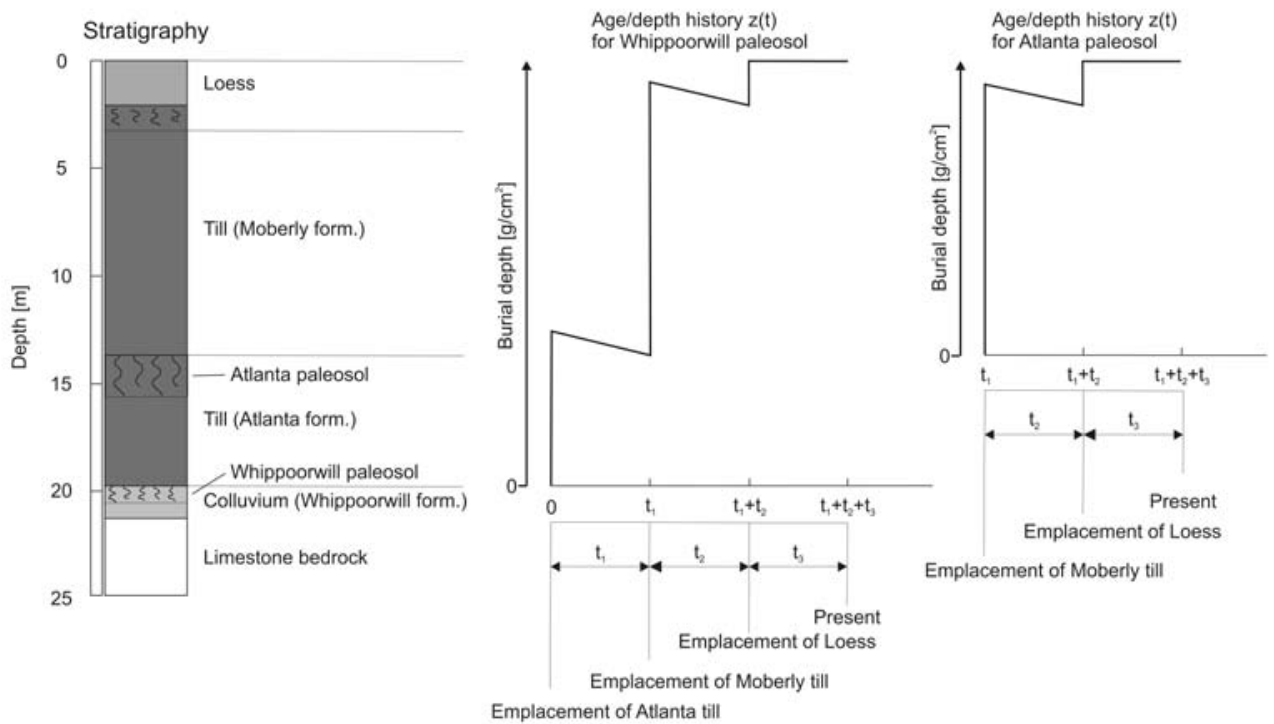

Fig. 5: Overview of the Musgrove section, Missouri, USA. Left part shows idealised stratigraphic sketch with used stratigraphic units. Right part visualise the used three-step density build-up model with rapid burial followed by moderate surface erosion. Modified after BALCO et al. (2005).

Abb. 5: Schematische Darstellung des Musgrove Profils, Missouri, USA. Links: vereinfachtes stratigraphisches Profil mit Tiefenangaben. Rechts: Veranschaulichung der Entwicklung der Überlagerungsmächtigkeiten im angewendeten dreiphasigen Modell mit rascher Überdeckung und anschließender gemäßigter Oberflächenerosion. Verändert nach BALCO et al. (2005). 
to date glacially related gravel successions in the Bavarian foreland of the Alps, Germany, at an abandoned gravel quarry near Bad Grönenbach, and in a second site, Böhener Feld. Both sites are made up of a mixture of limestone and quartz gravels in a carbonate matrix. The pioneer work on alpine Quaternary geology by PENCK \& BRÜCKNER (1909) named these gravels "Deckenschotter" (cover gravels) and placed them within the classical Mindelian (Bad Grönbach) and the Günzian (Böhner Feld) glaciation, respectively. The age and terrace erosion rate determination of Häuselmann et al. (2007) follows the nuclide profiling approach of GRANGER \& SMITH (2000), as described above, followed by a $\chi^{2}$ minimisation. This resulted in a fitted burial age of $0.68^{+0.23 /}{ }_{-0.24} \mathrm{Ma}$ and a terrace erosion rate of $123^{+139}{ }_{-32} \mathrm{~m} \mathrm{Ma}^{-1}$ at Bad Grönenbach, and $2.35^{+1.08 /}{ }_{-0.88} \mathrm{Ma}$ and an erosion rate of 18 $+10 /{ }_{-4} \mathrm{~m} \mathrm{Ma}^{-1}$ for the section at Böhener Feld. This work was the first attempt to absolutely date these gravel deposits and demonstrates the suitability of the burial dating approach using ${ }^{10} \mathrm{Be}$ and ${ }^{26} \mathrm{Al}$ within the time span of the Quaternary, although relatively high measuring uncertainties, due to the abundance of common $\mathrm{Al}$ impurities in the processed quartz, result in large model uncertainties and subsequently in large errors. This work also demonstrated that sample preparation and nuclide measurements are still delicate tasks.

The three examples described above, can explain the build-up of terraces in a single depositional event, which may occur over hundreds or even thousands of years. Cosmogenic burial dating of more complex deposit evolution is also possible, as long as a well constrained stratigraphy is available. In such a sedimentary sequence, each package will have its own deposition age and burial history that is determined by the deposition age of the following layer. BALCO et al. (2005) describe the age determination of such a multiple package set-up. They dated a profile containing three palaeosols buried beneath Laurentide Ice Sheet sediments and a loess cover. At the Musgrove clay pit, Missouri, USA, two tills, the Atlanta and Moberly formations, overlie deeply weathered bedrock, as well as locally derived colluvium of the Whippoorwill formation (Fig. 5). BALCo et al. (2005) developed a three step burial history for the Musgrove section with rapid burial and moderate surface erosion (Fig. 5). Using Monte Carlo simulations in MATLAB's Optimization Toolbox enables minimisation of $\chi^{2}$ discrepancies between model and measurements. In doing so, they determine a burial age of $2.41 \pm 0.14 \mathrm{Ma}$ for the lower till section (Atlanta formation) and, one between 1.6 - 1.8 Ma for the upper till (Moberly formation).

It should be noted, however, that it was necessary to assume some initial conditions in order to complete this well-developed model. BALCO et al. (2005) chose an age of $125 \mathrm{ka}$ for the deposition of the covering loess layer based on regional stratigraphy (identified by $t_{3}$ in Fig. 5). This assumption consequently affects all other age calculations in the used stepwise model (age of Atlanta till $=\mathrm{t}_{1}+\mathrm{t}_{2}+\mathrm{t}_{3}$ ). This approach is, therefore, not an independent age determination as is normally assumed with the burial dating method, although it should be noted that a stratigraphical age of $125 \mathrm{ka}$ for the loess is convincing and that BALCO et al. (2005) subsequently correlated the age of $2.41 \mathrm{Ma}$ with a (global) ice sheet build up from 2.7 to $2.4 \mathrm{Ma}$, as suggested by marine oxygen isotope data (JoyCE et al. 1993).

\subsection{Complex sediment burial histories}

The history of sediments in the natural environment is often highly complex. The material undergoes several kinds of transportation usually involving multiple stages of exposure and burial from its source until its modern day position. It is often impossible to describe the complete transportation history with confidence.

In these situations the in situ cosmogenic nuclides ${ }^{10} \mathrm{Be}$ and ${ }^{26} \mathrm{Al}$ may provide useful information regarding, whether sediment has been buried or not. In some cases it is possible to evaluate cumulative burial and exposure durations.

The first use of the ${ }^{10} \mathrm{Be} /{ }^{26} \mathrm{Al}$ ratio was done by KLEIN et al. (1986). They looked at 12 Libyan 
Dessert Glass samples, subdivided into three groups. Fission-track dating placed the age at $28.5 \mathrm{Ma}$, but in situ cosmogenic ${ }^{10} \mathrm{Be}$ and ${ }^{26} \mathrm{Al}$ concentrations did not agree with this estimate. KLEIN et al. (1986) attempted to solve this discrepancy with regard to the history of the Libyan Dessert Glass and the distribution of nuclide concentrations within the individual groups. By analysing the ratio of ${ }^{10} \mathrm{Be}$ and ${ }^{26} \mathrm{Al}$ they could clearly show that burial by sand dunes is the most plausible explanation for the obtained nuclide concentrations. Furthermore they presented the first (minimum) burial ages based on the simplification of a single exposure followed by a single burial. The article of KLEIN et al. (1986) marks the advent of "burial dating with in situ produced cosmogenic nuclides".

A second interesting application of the ${ }^{10} \mathrm{Be} /{ }^{26} \mathrm{Al}$ ratio in the early stage of burial dating development is documented by AlBRECHT et al. (1993), working on volcanic ash-flow tuffs at the Pajarito plateau of the Valles caldera, New Mexico, USA. These surfaces are part of the Tshirege member of the Bandelier Tuff, which was deposited during a caldera eruption at $\sim 1.14 \mathrm{Ma}$. The Tshirege member can be subdivided into four subunits, each with its own erosive character. The analysis of nuclide concentrations of ${ }^{10} \mathrm{Be}$ and ${ }^{26} \mathrm{Al}$ identified two to five times lower concentrations than a $1.14 \mathrm{Ma}$ exposure history should yield, which was mainly due to erosion and previous burial of the investigated surfaces. Albrecht et al. (1993) suggested a burial period of $0.6 \pm 0.3 \mathrm{Ma}$ for most of the studied samples by using the ${ }^{26} \mathrm{Al} /{ }^{10} \mathrm{Be}$ ratio. The former shielding of the sampled surface is explained by an eroded tuff and soil cover consisting of the overlaying subunits of the Tshirege member with an average thickness of $\sim 6 \mathrm{~m}$.

Burial by overlaying sediment is not the only explanation for a complex burial history. The shielding material does not necessarily have to be rock or sediment to result in the attenuation of secondary cosmic ray particle energy, which is dependent on the density of the overburden material. Thus any matter may shield cosmic radiation, with rock causing the most effective

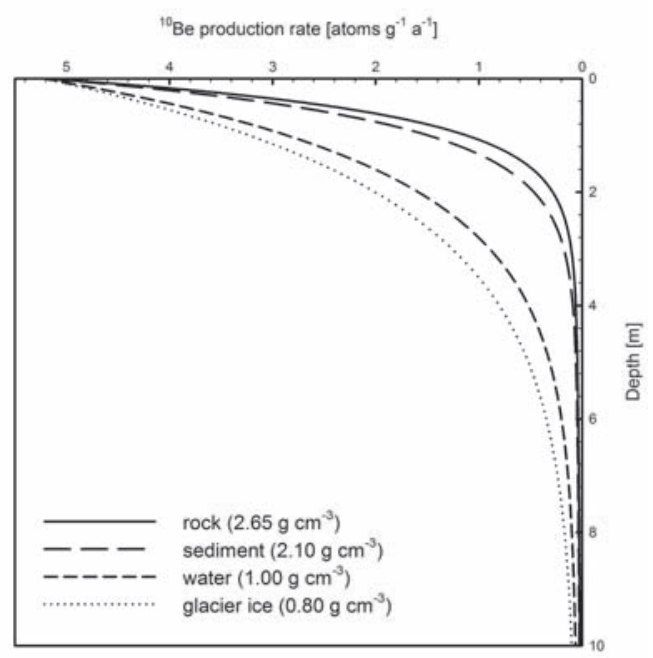

Fig. 6: Illustration of decreasing ${ }^{10} \mathrm{Be}$ production rate (at SLHL) caused by increasing shielding for typical geological overburdens with average densities at various depths. "Hard" overburdens such as rock or sediment obtain shielding rates of $90 \%$ in depth of $\sim 1.8 \mathrm{~m}$, while "soft" materials such as water or glacial ice need to be of $\sim 4.5 \mathrm{~m}$ in thickness.

Abb. 6: Darstellung der ${ }^{10} \mathrm{Be}$ Produktionsratenabnahme bei zunehmender Überdeckung und damit steigender Abschirmung der kosmischen Strahlung (gültig für SLHL-Bedingungen).

Gezeigt sind ausgewählte geologisch typische Deckschichten mit ihren mittleren Dichten. „Harte“ Deckschichten wie Gestein oder Sediment erreichen Abschirmungsraten von $90 \%$ bereits in Tiefen von $\sim 1,8 \mathrm{~m}$, während ,weiche“ Materialien, wie Wasser oder Eis, eine Mächtigkeit von $\sim 4,5 \mathrm{~m}$ aufweisen müssen um die gleiche Abschirmung zu erreichen.

attenuation followed in order by sediment, water and glacial ice (Fig. 6).

Any shielding history is clearly shown by the position of the sample on a two-isotope diagram, for example ${ }^{26} \mathrm{Al} /{ }^{10} \mathrm{Be}$ ratios vs. ${ }^{10} \mathrm{Be}$ concentrations (Fig. 7), referred to as a "steadystate erosion island plot" (LAL 1991), "simple exposure island plot" or "banana plot". The two-isotope diagram allows the detection of any shielding of a sample during its history. The "zero erosion line" and the "steady-state erosion line" frame a banana shaped area on a plot with logarithmic abscissa referred to 




Fig. 7: Two-isotope diagram for in situ produced cosmogenic ${ }^{10} \mathrm{Be}$ and ${ }^{26} \mathrm{Al}$ in quartz as proposed by LAL (1991) with selected burial isochrones (dotted) and decay lines (dashed). Production rates are normalised to SLHL values with a ${ }^{26} \mathrm{Al} /{ }^{10} \mathrm{Be}$ production ratio of 6.1 . Decay lines are given for complete shielding after single exposure with selected erosion rates (in $\mathrm{mm} \mathrm{ka}^{-1}$ ) until reaching saturation. Samples that have been shielded will plot below the steady-state erosion line in that the ${ }^{26} \mathrm{Al} /{ }^{10} \mathrm{Be}$ ratio will decrease resulting from the shorter half live of ${ }^{26} \mathrm{Al}$ with respect to ${ }^{10} \mathrm{Be}$. Used parameters are listed in Table 1.

Abb. 7: Zwei-Isotopen-Diagram für in situ produziertes ${ }^{10} \mathrm{Be}$ und ${ }^{26} \mathrm{Al}$ in Quarz nach LAL (1991), mit ausgewählte Überlagerungsisochronen (gepunktet). Produktionsraten sind normalisiert auf SLHL-Bedingungen mit einem ${ }^{26} \mathrm{Al} /{ }^{10} \mathrm{Be}$ Produktionsverhältnis von 6,1. Zerfallsgeraden (gestrichelt) sind dargestellt für den Fall der vollständigen Abschirmung nach einmaliger, kontinuierlicher Bestrahlung für ausgewählte Erosionsraten (in $\mathrm{mm} \mathrm{ka}^{-1}$ ). Proben die während oder nach ihrer Bestrahlung abgeschirmt wurden, plotten unter der Gleichgewichts-Erosionsgeraden, da das ${ }^{26} \mathrm{Al} /{ }^{10} \mathrm{Be}$ Verhältnis abnimmt, gemäß der kürzeren Halbwertszeit des ${ }^{26} \mathrm{Al}$ Nuklids. $\mathrm{Zu}$ Grunde liegende Parameter können Tabelle 1 entnommen werden.

as the steady-state erosion island (LAL 1991). All samples with a nuclide inventory resulting from simple exposure will plot within this area, while samples that have also undergone some shielding will fall below that. A determination of burial duration is only possible for a single burial event. A discrete observation of multiple shielding events is not possible with the steadystate erosion island plot, as the measured nuclide inventory is a composite of all exposure and shielding periods. Nuclide concentrations and production rates have to be normalised to sea level, high latitude ( $>60^{\circ}$; SLHL) values to avoid any affects of production rate changes resulting from scaling to sample location (for more detailed discussion of two-isotope diagrams see LAL 1991; BIERMAN et al. 1999; Gosse \& PhiLlips 2001).

Shielding by material other than sediment or rock was studied by BIERMAN et al. (1999), who measured ${ }^{10} \mathrm{Be}$ and ${ }^{26} \mathrm{Al}$ concentrations at two locations at the northern and southern margin of the former Laurentide Ice Sheet. The northern site around Pangnirtung on Baffin Island, Canada consists of in situ deeply weathered Precambrian gneissic bedrock. In the area around these tor samples neither bedrock nor boulders display striations, grooves or chattermarks, although erratic cobbles and boulders confirm the presence of glacial ice. The southern part near Pipestone, Minnesota, USA is made up of very erosion resistant Sioux Quartzite. Its surface 
preserves ice-flow indicators which have subsequently been wind polished and cross-cut by shallower grooves, and earlier studies suggested that the areas were ice-free during the last glaciation. BIERMAN et al. (1999), however, determined ${ }^{26} \mathrm{Al} /{ }^{10} \mathrm{Be}$ ratios that are less than the production ratio of $\sim 6.1$ within the bedrock that do not support a single exposure history, and suggest the areas must have been shielded from cosmic radiation at some point during and/or after initial exposure. On the one hand, young exposure ages (see Ivy-Ochs \& KOBER 2008) of the sampled erratics, lying on the modern surface, suggest deposition by ice during the Last Glacial Maximum (LGM, $14-30 \mathrm{ka}$ ). On the other hand, high nuclide concentrations within the bedrock do not support glacial cover during the LGM, due to the lack of glacial erosion and therefore the lowering of nuclide concentration. To explain these opposing observations BiERMAN et al. (1999) suggest cover by coldbased glaciers that would have not eroded the underlying bedrock and therefore would have not reset the "cosmogenic exposure clock". By modelling different exposure-burial scenarios they identified that the Sioux Quartzite samples have minimum total burial times that are more than twice as long as minimum exposure times, with an average minimum burial duration of $414 \pm 29 \mathrm{ka}$. For the northern edge of the former Laurentide Ice Sheet on Baffin Island they conclude from ${ }^{10} \mathrm{Be}$ and ${ }^{26} \mathrm{Al}$ data, a non-erosive cold-based ice or deep snowfield cover for at least $400 \mathrm{ka}$.

A similar approach was used by StroEven et al. (2002) and FABEL et al. (2002) who investigated ancient landscapes in Northern Sweden as relicts of the Fennoscandian Ice Sheet, to test the hypothesis of landscape preservation through multiple glacial cycles. Stroeven et al. (2002) investigated three tor samples and a bedrock outcrop in a meltwater channel in the Parkajoki area. The meltwater channel data are an exposure age of $11 \pm 3 \mathrm{ka}$ for both ${ }^{10} \mathrm{Be}$ and ${ }^{26} \mathrm{Al}$, as a reliable deglaciation age. The lowered ${ }^{26} \mathrm{Al} /{ }^{10} \mathrm{Be}$ ratios of the tors, however, suggest that the sampled relict landscapes did not undergo a single exposure history, as re- ported in the regional literature. FABeL et al. (2002) looked at bedrock outcrops and erratics on relict surfaces in the northern Swedish mountains. These yield deglaciation ages of $\sim 8-12$ ka with ${ }^{10} \mathrm{Be}$ surface exposure dating of the erratics but much older surface ages of $\sim 33-60 \mathrm{ka}$ for the bedrock, similar to StroeVEN et al. (2002). These researchers refined the approach described by BIERMAN et al. (1999) by using the marine benthic foraminifer oxygen isotope record of global ice volume from DSDP 607 , as a proxy for the duration of periods of ice sheet cover vs. ice free conditions. They postulated 11 exposure and 10 burial events with a combined duration of 128 and $477 \mathrm{ka}$ respectively for the Parkajoki area and a mean exposure-burial duration of 45 and $800 \mathrm{ka}$ for the northern Swedish mountains.

\section{Summary and outlook}

The recent advances in terrestrial cosmogenic nuclides in geology and geomorphology have only been possible following the development of accelerator mass spectrometry in the late 1970's and early 1980's (see FinKel \& SUTER 1993), although the first burial and exposure histories were too complex and so difficult to interpret and provide reliable ages. $\mathrm{A}^{26} \mathrm{Al} /{ }^{10} \mathrm{Be}$ ratio significant lower than the production ratio was believed to indicate that the samples had been buried before, and only minimum burial ages could be constrained. After identifying that cave environments provide the ideal shielding scenario (instantaneous and sufficient), which prevents post burial nuclide production, it was possible to produce absolute burial ages from ${ }^{10} \mathrm{Be}$ and ${ }^{26} \mathrm{Al}$ determinations (GRANGER et al. 1997). This step, around 10 years ago, marked the beginning of "real" cosmogenic burial dating. In the last few years, burial dating has been applied using the nuclide profiling approach, to more complex environments such as alluvial fans (MATMON et al. 2005), fluvial terraces (WOLKOWINSKY \& GRANGER 2004) or to relict surfaces beneath glacial ice that undergo partial shielding (StAIGER et al. 2005; Briner et al. 2006; DAvis et al. 2006). Nevertheless, this 
often produces relatively large uncertainties that result in scepticism outside the cosmogenic community. As already shown, however, dating with cosmogenic nuclides offers unique advantages: application to quartz, the most common mineral on Earth's surface, and a time range of $100 \mathrm{ka}$ to $5 \mathrm{Ma}$, making it very attractive to geomorphologists, (Quaternary) geologists and palaeoanthropologists.

Although fundamentals underlying its application have been recognised for almost 70 years, burial dating using cosmogenic nuclides is a relatively new technique and it is likely that in future nuclide pairs other than the ${ }^{10} \mathrm{Be} /{ }^{26} \mathrm{Al}$ one will be used. The shorter half-life of radiocarbon, $5730 \pm 40$ years (GodwIN 1962), would enable burial dating in the order of thousands to tens of thousands of years and allow the dating of more recent processes using the ${ }^{10} \mathrm{Be} /{ }^{14} \mathrm{C}$ pair in quartz. Additionally, slowly eroding rocks should have inherited ${ }^{14} \mathrm{C}$ concentrations close to saturation and would allow burial age determination without any other nuclides as initial nuclide concentration is reasonably well known. The ${ }^{10} \mathrm{Be} /{ }^{36} \mathrm{Cl}$ pair is also of interest, and would allow burial age determinations within carbonate rich and mafic environments. The first step towards the use of this nuclide pair has been made recently by BRAUCHER et al. (2006) who investigated the in situ ${ }^{10} \mathrm{Be}$ production rate and the chemical behaviour of ${ }^{10} \mathrm{Be}$ in carbonates as well as clinopyroxene samples. They identified a normalised ${ }^{10} \mathrm{Be}$ production rate of $37.9 \pm 6.0$ atoms $\mathrm{g}^{-1} \mathrm{a}^{-1}$ in calcite and 3.1 \pm 0.8 atoms $\mathrm{g}^{-1} \mathrm{a}^{-1}$ in clinopyroxenes using the longer half life of $\sim 1.5 \mathrm{Ma}$, and also presented laboratory protocols for the in situ ${ }^{10} \mathrm{Be}$ extraction from calcite and pyroxene samples.

New cosmogenic nuclide systems or combinations will be of interest in the coming years and the ongoing evaluation of physical constraints such as nuclide half lives (see chapter 1), nuclide production rates, muon production effects in depth and general long term production effects will also improve the precision of the general cosmogenic nuclide approach. The burial dating method stands today at a reasonably wellunderstood experimental level, although model evaluations and sensitivity tests are often not considered, or only partially understood, as a result of lack available data, compared to other well established dating techniques, such as radiocarbon, uranium/thorium or luminescence dating. This situation will change in the future through further research and the discovery of new applications.

\section{Acknowledgements}

We would like to thank Philipp Häuselmann, Susan Ivy-Ochs and an anonymous reviewer for their helpful reviews, Oliver Kracht for his constructive comments and Sally Lowick for improving the English of the manuscript. This work is supported by the Swiss National Science Foundation (project no. 200020-105220).

\section{References}

AKÇAR, N., Ivy-Ochs, S. \& SChlÜChter, C. (2008): Application of in-situ produced terrestrial cosmogenic nuclides to archaeology: A schematic review. - Quaternary Science Journal (Eiszeitalter und Gegenwart): 57/1-2: 226-238.

Albrecht, A., Herzog, G.F., Klein, J., DezfoulyArjomandy, B. \& GoFf, F. (1993): Quaternary erosion and cosmic-ray-exposure history derived from ${ }^{10} \mathrm{Be}$ and ${ }^{26} \mathrm{Al}$ produced in situ - An example from Pajarito plateau, Valles caldera region. - Geology, 21: 551-554.

Asfaw, B., White, T.D., Lovejoy, O., Latimer, B., Simpson, S. \& Suwa, G. (1999): Australopithecus garhi: A new species of early hominid from Ethiopia. - Science, 284: 629.

Balco, G., Rovey, C.W. \& Stone, J.O.H. (2005): The first glacial maximum in North America. - Science, 307: 222-222.

Bierman, P.R., Marsella, K.A., Patterson, C., Davis, P.T. \& Caffee, M. (1999): Mid-Pleistocene cosmogenic minimum-age limits for preWisconsinan glacial surfaces in southwestern Minnesota and southern Baffin island: a multiple nuclide approach. - Geomorphology, 27: 25-39.

Braucher, R., Blard, P.-H., Benedetti, L. \& BourLÈs, D.L. (2006): Extending ${ }^{10} \mathrm{Be}$ applications to carbonate-rich and mafic environments. - In: L.L. Siame, D.L. Bourlès \& E.T. Brown (eds.): In Situ-Produced Cosmogenic Nuclides and Quantification of Geoloigcal Processes: 17-28; 
Boulder, Colorado (The Geological Society of America).

Briner, J.P., Miller, G.H., Davis, P.T. \& Finkel, R.C. (2006): Cosmogenic radionuclides from fiord landscapes support differential erosion by overriding ice sheets. - Geological Society of America Bulletin, 118: 406-420.

Brown, E.T., Brook, E.J., Raisbeck, G.M., Yiou, F. \& KuRz, M.D. (1992): Effective attenuation lengths of cosmic rays producing ${ }^{10} \mathrm{Be}$ and ${ }^{26} \mathrm{Al}$ in quartz: implications for exposure age dating. - Geophysical Research Letters, 19: 369-372.

Brown, E.T., Edmond, J.M., Raisbeck, G.M., Yiou, F., Kurz, M.D. \& BrooK, E.J. (1991): Examination of surface exposure ages of Antarctic moraines using in situ produced ${ }^{10} \mathrm{Be}$ and ${ }^{26} \mathrm{Al}$. - Geochimica et Cosmochimica Acta, 55: 22692283.

Clark, J.D., Beyene, Y., WoldeGabriel, G., Hart, W.K., Renne, P.R., Gilbert, H., Defleur, A., Suwa, G., Katoh, S., Ludwig, K.R., Boisserie, J.-R., Asfaw, B. \& White, T.D. (2003): Stratigraphic, chronological and behavioural contexts of Pleistocene Homo sapiens from Middle Awash, Ethiopia. - Nature, 423: 747-752.

Davis, P.T., Briner, J.P., Coulthard, R.D., Finkel, R.W. \& Miller, G.H. (2006): Preservation of Arctic landscapes overridden by cold-based ice sheets. - Quaternary Research, 65: 156-163.

Desilets, D. \& Zreda, M. (2001): On scaling cosmogenic nuclide production rates for altitude and latitude using cosmic-ray measurements. - Earth and Planetary Science Letters, 193: 213-225.

Dèzes, P., Schmid, S.M. \& Ziegler, P.A. (2004): Evolution of the European Cenozoic Rift System: interaction of the Alpine and Pyrenean orogens with their foreland lithosphere. - Tectonophysics, 389: 1-33.

DunAI, T.J. (2000): Scaling factors for production rates of in situ produced cosmogenic nuclides: a critical reevaluation. - Earth and Planetary Science Letters, 176: 157-169.

Fabel, D., Stroeven, A.P., Harbor, J., Kleman, J., Elmore, D. \& FinK, D. (2002): Landscape preservation under Fennoscandian ice sheets determined from in situ produced ${ }^{10} \mathrm{Be}$ and ${ }^{26} \mathrm{Al}$. - Earth and Planetary Science Letters, 201: 397406.

FinK, D. \& Sмiтh, A. (2007): An inter-comparison of ${ }^{10} \mathrm{Be}$ and ${ }^{26} \mathrm{Al}$ AMS reference standards and the ${ }^{10} \mathrm{Be}$ half-life. - Nuclear Instruments and Methods in Physics Research Section B - Beam
Interactions with Materials and Atoms, 259: 600-609.

Finkel, R.C. \& Suter, M. (1993): AMS in the Earth sciences: technique and applications. - In: M. Hyman \& M.W. Rowe (eds.): Advances in analytical geochemnistry: 1-114; Greenwich (Jai Press Inc.).

Gibbard, P.L., Smith, A.G., Zalasiewicz, J.A., Barry, T.L., Cantrill, D., Coe, A.L., Cope, J.C.W., Gale, A.S., Gregory, F.J., Powell, J.H., Rawson, P.F., Stone, P. \& Waters, C.N. (2005): What status for the Quaternary? - Boreas, 34: $1-6$.

Godwin, H. (1962): Half-live of radiocarbon. - Nature, 195: 984.

Gosse, J.C. \& Phillips, F.M. (2001): Terrestrial in situ cosmogenic nuclides: theory and application. - Quaternary Science Reviews, 20: 1475-1560.

GrangER, D.E. (2006): A review of burial dating methods using ${ }^{26} \mathrm{Al}$ and ${ }^{10} \mathrm{Be}$. - In: L.L. SiAme, D.L. Bourlès \& Brown, E.T. (eds.): In Situ-Produced Cosmogenic Nuclides and Quantification of Geological Processes: 1-16; Boulder, Colorado (The Geological Society of America).

Granger, D.E. \& Smith, A.L. (2000): Dating buried sediments using radioactive decay and muogenic production of ${ }^{26} \mathrm{Al}$ and ${ }^{10} \mathrm{Be}$. - Nuclear Instruments and Methods in Physics Research Section B - Beam Interactions with Materials and Atoms, 172: 882-826.

Granger, D.E. \& MuZIKAR, P.F. (2001): Dating sediment burial with in situ-produced cosmogenic nuclides: theory, techniques, and limitations. - Earth and Planetary Science Letters, 188: 269-281.

Granger, D.E., Kirchner, J.W. \& Finkel, R.C. (1997): Quaternary downcutting rate of the New River, Virginia, measured form differential decay of cosmogenic ${ }^{26} \mathrm{Al}$ and ${ }^{10} \mathrm{Be}$ in cave-deposited alluvium. - Geology, 25: 107-110.

Granger, D.E., Fabel, D. \& Palmer, A.N. (2001): Pliocene-Pleistocene incision of the Green River, Kentucky, determined from radioactive decay of cosmogenic ${ }^{26} \mathrm{Al}$ and ${ }^{10} \mathrm{Be}$ in Mammoth Cave sediments. - GSA Bulletin, 113: 825-836.

Granger, D.E., Cyr, A.J. \& Partridge, T.C. (2006): Quantitative tests of cosmogenic nuclide burial dating accuracy. - Geochimica et Cosmochimica Acta, 70, Supplement 1: A212.

Häuselmann, P., Granger, D.E., Jeannin, P.-Y. \& LAURITZEN, S.-E. (2007): Abrupt glacial valley incision at $0.8 \mathrm{Ma}$ dated from cave deposits in Switzerland. - Geology, 35: 143-146. 
Häuselmann, P. \& Granger, D.E. (2005): Dating of caves by cosmogenic nuclides: Method, possibilities, and the Siebenhengste example (Switzerland). - Acta Carsologica, 34: 43-50.

Häuselmann, P., Fiebig, M., Kubik, P.W. \& Adrian, H. (2007): A first attempt to date the orginal "Deckenschotter" of Penk \& Brückner with cosmogenic nuclides. - Quaternary International, 164-165: 33-42.

HAJDAS, I. (2008):Radiocarbon dating and its applications in Quaternary studies - Quaternary Science Journal (Eiszeitalter und Gegenwart), 57/1-2: 2-24.

Heisinger, B.P. (1998): Myonen-induzierte Produktion von Radionukliden. - 153 S., Ph.D. thesis; Technische Universität München, München.

Hofmann, H.J., Beer, J., Bonani, G., von Gunten, H.R., Raman, S., Suter, M., Walker, R.L., Wölfli, W. \& ZimmermanN, D. (1987): 10Be: half-life and AMS-standards. - Nuclear Instruments and Methods in Physics Research Section B - Beam Interactions with Materials and Atoms, 29: 32-36.

Ivy-Ochs, S. \& Kober, F. (2008): Surface exposure dating with cosmogenic nuclides. - Quaternary Science Journal (Eiszeitalter und Gegenwart, 57/1-2: 179-209.

Joyce, J.E., TJaisma, L.R.C. \& Prutzman, J.M. (1993): North American glacial meltwater history for the past 2.3 m.y.: Oxygen isotope evidence from the Gulf of Mexico. - Geology, 21: 483-486.

Klein, J., Giegengack, R., Middleton, R., Sharma, P., Underwood, J.R. \& WeeKs, R.A. (1986): Revealing histories of exposure using in situ produced ${ }^{26} \mathrm{Al}$ and ${ }^{10} \mathrm{Be}$ in Libyan Desert Glass. - Radiocarbon, 28: 547-555.

LAL, D. (1991): Cosmic ray labeling of erosion surfaces: in situ nuclide production rates and erosion models. - Earth and Planetary Science Letters, 104: 424-439.

LaL, D. \& Peters, B. (1967): Cosmic ray produced radioactivity on the Earth. - In: S. FLÜGGE (eds.): Handbuch der Physik = Encyclopedia of physics: 551-612; Berlin (Springer Verlag).

LAL, D. \& ARnold, J.R. (1985): Tracing Quartz through the Environment. - Proceedings of the Indian Academy of Sciences-Earth and Planetary Sciences, 94: 1-5.

Matmon, A., Schwartz, D.P., Finkel, R., Clemmens, S. \& Hanks, T. (2005): Dating offset fans along the Mojave section of the San Andreas fault using cosmogenic ${ }^{26} \mathrm{Al}$ and ${ }^{10} \mathrm{Be}$. - GSA Bulletin, 117: 795-807.
Middleton, R., Klein, J., Raisbeck, G. \& Yiou, F. (1983): Accelerator mass spectrometry with ${ }^{26} \mathrm{Al}$. - Nuclear Instruments and Methods in Physics Research, 218: 430-438.

Middleton, R., Brown, L., Dezfouly-Arjomandy, B. \& Klein, J. (1993): On ${ }^{10} \mathrm{Be}$ standards and the half-Life of ${ }^{10} \mathrm{Be}$. - Nuclear Instruments and Methods in Physics Research Section B - Beam Interactions with Materials and Atoms, 82: 399403.

Nishizzumi, K., Imamura, M., Caffee, M.W., SouTHON, J.R., FinKEL, R.C. \& McANinch, J. (2007): Absolute calibration of ${ }^{10} \mathrm{Be}$ AMS standards. - Nuclear Instruments and Methods in Physics Research Section B - Beam Interactions with Materials and Atoms, 258: 403-413.

Norris, T.L., Gancarz, A.J., Rokop, D.J. \& Thomas, K.W. (1983): Half-life of ${ }^{26} \mathrm{Al}$. - Proceedings of the fourteenth Lunar and Planetary Science Conference, Part I, Journal of Geophysical Research, 88 (Supplement): B331-B333.

Partridge, T.C., Granger, D.E., Caffee, M.W. \& Clarke, R.J. (2003): Lower Pliocene hominid remains from Sterkfontein. - Science, 300: 607612.

Penck, A. \& BrüCKner, E. (1909): Die Alpen im Eiszeitalter. - 1199 S.; Leipzig (Tauchnitz).

Pickering, R., Hancox, P.J., Lee-Thorp, J.A., Grün, R., Mortimer, G.E., McCulloch, M. \& Berger, L.R. (2007): Stratigraphy, U-Th chronology, and paleoenvironments at Gladysvale Cave: insights into the climatic control of South African hominin bearing cave deposits. - Journal of Human Evolution, 53: 602-619.

Preusser, F., Deggering, D., Fuchs, M., Hilgers, A., Kadereit, A., Klasen, N., Krbetschek, M., Richter, D., Spencer, J. 2008. Luminescence dating: Basics, methods and applications. Quaternary Science Journal (Eiszeitalter \& Gegenwart), 57/1-2: 95-149.

Ravelo, A.C., Andreasen, D.H., Lyle, M., Lyle, A.O. \& WARA, M.W. (2004): Regional climate shifts caused by gradual global cooling in the Pliocene epoch. - Nature, 429: 263-267.

Rightmire, R.A., Kohman, T.P. \& Hintenberger, H. (1958): Über die Halbwertszeit des langlebigen ${ }^{26}$ Al. - Zeitschrift für Naturforschung Teil A - Astrophysik, Physik, Physikalische Chemie, 13: 847-853.

Sharma, P. \& Middleton, R. (1989): Radiogenic production of ${ }^{10} \mathrm{Be}$ and ${ }^{26} \mathrm{Al}$ in uranium and thorium ores: Implications for studying terrestrial samples containing low levels of ${ }^{10} \mathrm{Be}$ and 
${ }^{26} \mathrm{Al}$. - Geochimica et Cosmochimica Acta, 53: 709-716.

Staiger, J.K.W., Gosse, J.C., Johnson, J.V., Fastook, J., Gray, J.T., Stockli, D.F., Stockli, L. \& FINKEL, R. (2005): Quaternary relief generation by polythermal glacier ice. - Earth Surface Processes and Landforms, 30: 1145-1159.

Stone, J.O. (2000): Air pressure and cosmogenic isotope production. - Journal of Geophysical Research B, 105: 23753-23759.

Stroeven, A.P., Fabel, D., Hättestrand, C. \& HarBOR, J. (2002): A relict landscape in teh centre of Fennoscandian glaciation: cosmogenic radionuclide evidence of tors preserved through multiple glacial cycles. - Geomorphology, 44: 145-154.
Wagner, G., Masarik, J., Beer, J., Baumgartner, S., Imboden, D., Kubik, P.W., Synal, H.-A. \& Suter, M. (2000): Reconstruction of the cosmogenic field between 20 and $60 \mathrm{kyr}$ BP form cosmogenic radionuclides in the GRIP ice core. - Nuclear Instruments and Methods in Physics Research Section B - Beam Interactions with Materials and Atoms, 172: 597-604.

Walker, J., Cliff, R.A. \& Latham, A.G. (2006): U$\mathrm{Pb}$ isotopic age of the $\mathrm{StW} 573$ hominid from Sterkfontein, South Africa. - Science, 314: 1592-1594.

Wolkowinsky, A.J. \& Granger, D.E. (2004): Early Pleistocene incision of the San Juan River, Utah, dated with ${ }^{26} \mathrm{Al}$ and ${ }^{10} \mathrm{Be}$. - Geology, 32: 749-752. 